\title{
Anthropocene and early human behavior
}

\begin{abstract}
When is the baseline for Anthropocene? The first indications of human impact on earth closely relate to early human behavior and use of resources. First agricultural societies modified the landscape with the aim of generating their own resources to satisfy the needs of an increasing population. This new system was the result of years of learning and continuous interaction with landscape. Hunter-gatherer societies had shown a vast knowledge of their surrounding environment, which allowed them to exploit and optimize the available resources. But, had these societies the capacity to modify the landscape in such a way that can be traced up until today? How far back in time can we go to find the first evidence of human impact on earth? In this paper, we will try to analyze early human behavior and the possible impact of their activities on the landscape. We will use the paleoanthropological site of Olduvai Gorge (northern Tanzania) as a case study to suggest that the baseline for Anthropocene, taking the term as human impact on earth through cognitive-behavioral strategies, can be moved back to the time when early hominins visited Olduvai. Olduvai Gorge is perfectly suited for this study since the latest scientific research and publications have yielded a detailed knowledge of the vegetation, the landscape, and of the wildlife that lived in the area.
\end{abstract}

\section{Keywords}

Anthropocene, fire, human behavior, landscape interaction, Olduvai Gorge, phytoliths, plants, use of resources

Received II December 20I4; revised manuscript accepted 25 March 2015

\section{Introduction}

Every living thing affects its surrounding in different ways, and since humans learnt to control and modify the environment, the earth has dramatically been transformed and with uncertain results.

Crutzen and Stoermer (2000) and later on Crutzen (2002) introduced the term Anthropocene to define the geological epoch in which we live today and which started in the late 18th century: when analysis of air trapped in polar ice showed the beginning of growing global concentrations of carbon dioxide and methane. Along the years, the term has grown in use and popularity and discussions have arisen arguing against the beginning of this period. For example, Ruddiman (2003) developed the 'early Anthropocene' hypothesis, suggesting that human-induced changes in greenhouse gases did not begin in the 18th century, but in $8000 \mathrm{ka}$, as a result of intense farming activities during the Neolithic period. According to this author, it was at that time when the greenhouse gas concentrations stopped following the periodic pattern of rises and falls that had characterized their past long-term behavior (Ruddiman, 2003). Foley et al. (2013) use the term Anthropocene for the period starting in AD 1780 because of the sharp increase in $\mathrm{CO}_{2}$ emissions (Great acceleration), and introduce a new term, Paleoanthropocene, for the previous period. While they do not provide a precise initial date, they suggest that it may be related to the acquired knowledge of fire by early Homo populations. In the same line, Glickson (2013) proposes the use of early Anthropocene for the time when humans started to control fire, middle Anthropocene for the period corresponding to the beginning of agriculture and late Anthropocene for the outset of the industrial age.

Holocene human behavior, with the introduction of agriculture and herding practices, represents a turning point in human history. These new practices, probably related to a shift in climatic conditions marked by the appearance of the colder and drier Younger Dryas stadial (Bar-Yosef and Belfer-Cohen, 2002), evidenced a conscious modification of the landscape aimed at generating their own resources to satisfy the needs of an increasing population. This new system affected human populations not only at the social but also at the physical level with the introduction of new products for consumption. But this new mode of living is rooted far back in time, and it is the result of millions of years of gradual accumulation of knowledge and interaction with landscape. During the Plio-Pleistocene and the beginning of the Pleistocene, early Homo populations were already conducting activities addressed to provide themselves with the necessary resources for survival. These activities may relate to the acquisition of raw material to produce tools, possibly hunting and/or scavenging, gathering, and fire-making.

In this paper, we will try to assess the degree of impact of these activities on the landscape and on human behavior with a major emphasis on the acquisition and use of plant resources. We will use the site of Olduvai Gorge (Tanzania) as a case study, where our team (Olduvai Landscape Paleoanthropology Project - OLAPP) has been working since 2001. OLAPP results will be

IICREA (Catalan Institute for Research and Advanced Studies), Barcelona, Spain

2ERAAUB, Department of Prehistory, Ancient History and Archaeology, University of Barcelona, Spain

\section{Corresponding author:}

Rosa M Albert, ERAAUB, Department of Prehistory, Ancient History and Archaeology, University of Barcelona, c/ Montalegre 6-8, 0800 I Barcelona, Spain.

Email: rmalbert@ub.edu 


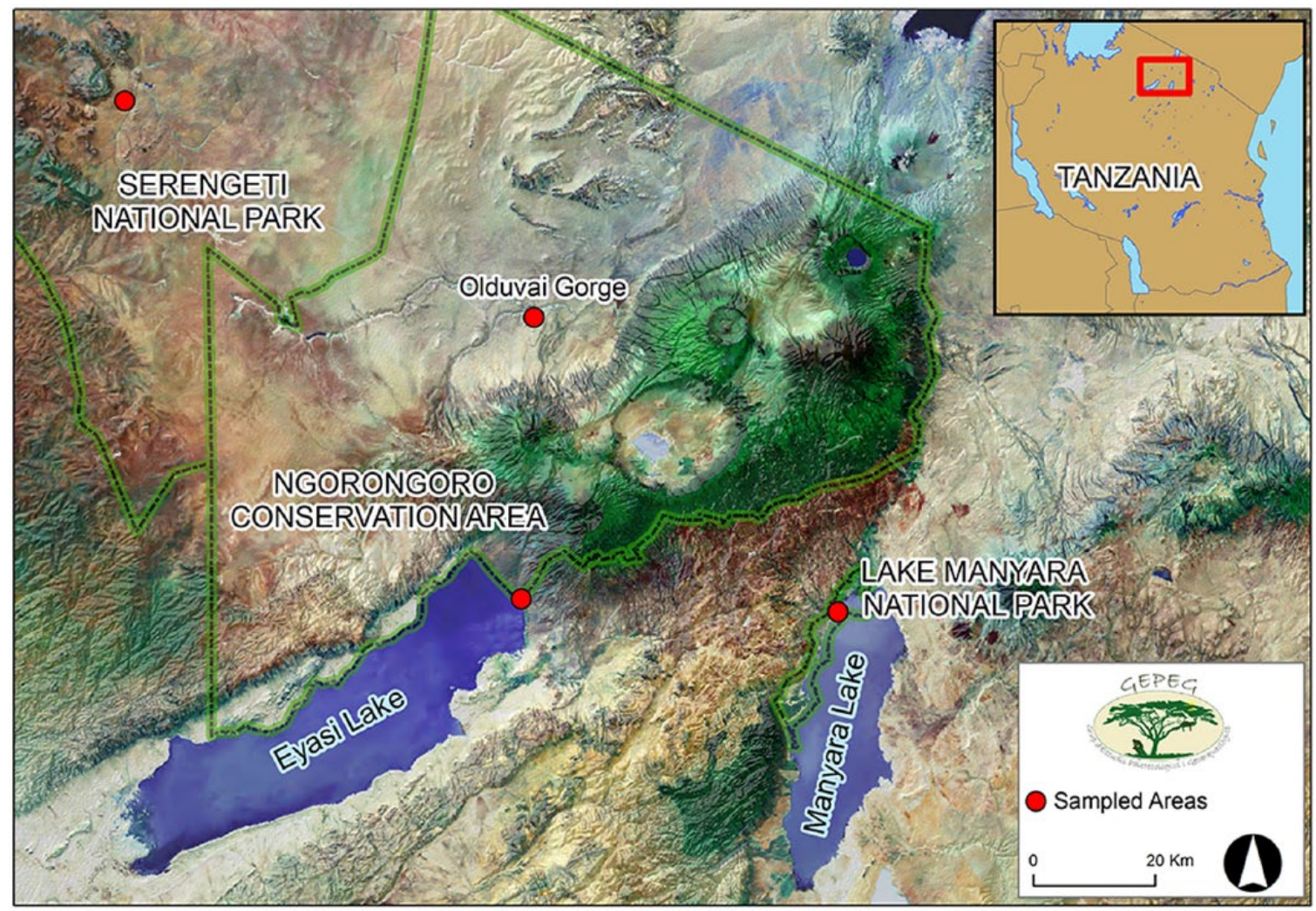

Figure I. Map of the Olduvai Gorge area in northern Tanzania in relation to the location of the modern study areas used to conduct actualistic studies.

compared with those obtained from other teams currently working at the Gorge: TOPPP (Olduvai Paleoanthropology and Paleoecology Project) (2006-present) and OGAP (Olduvai Geochronology and Archaeology Project) (2009-present). With this study, we aim to provide a deep-time perspective of Holocene human behavior through time.

\section{Why Olduvai Gorge?}

Olduvai Gorge is located in northern Tanzania to the east of the Ngorongoro Crater Highlands and the west of the Serengeti National Park in the Eastern Rift Valley (Figure 1). The Gorge is approximately $49-\mathrm{km}$ long and has a $90-\mathrm{m}$ section formed by lacustrine, fluvial, eolian, and pyroclastic sediments.

Although the site was excavated for the first time in 1913, it did not become famous worldwide until 1959 with Mary Leakey's discovery of the skull of Paranthropus boisei (OH5; known as 'Nutcracker Man' because of its powerful jaw). One year later, a fragment of upper maxilla of Homo habilis $(\mathrm{OH} 7)$ was recovered in the same chronological levels and a few meters to the northeast. These recoveries were chronometrically dated (K-Ar) to $1.75 \mathrm{Ma}$ and demonstrated for the first time the coexistence of two ancient hominins (Leakey, 1961). Subsequent explorations and excavations at the Gorge by different teams have resulted in the recovery of further hominin specimens including $P$. boisei and H. habilis, in Bed I and Lowermost Bed II (LMBII), and Homo erectus (Upper Bed II (UBII) and Beds III/IV). These H. erectus remains were dated to 1.2-1.1 Ma (Leakey, 1961; Rightmire, 1979; Tamrat et al., 1995). The site is also known for the rich collection of artifacts recovered including stone tools and processed bones (Leakey, 1971).

Olduvai Gorge has a long and well-documented stratigraphy covering more than 2 million years of earth history, which greatly facilitates the diachronic study to contextualize the paleoanthropological and archaeological remains chronologically and stratigraphically (Hay, 1976; Stanistreet, 2012; Stollhofen and
Stanistreet, 2012). Richard Hay subdivided the Plio-Pleistocene basin of Olduvai into seven formations (Beds I-IV, Masek Beds, Ndutu Beds, and Naisiusiu Beds) (Figure 2) (Hay, 1976). Later on, McHenry et al. (2008) included the Naabi Ignimbrite in Bed I. Despite faults across the paleobasin being already recognized by Hay (1976), recent research has identified fault compartments (the area between adjacent faults). The faults are considered to have had a minor effect on the topography but a significant effect on the soils and paleodrainage (Stollhofen and Stanistreet, 2012). This, together with climate change, in turn affected the flora, fauna, and hominin land use in close association with the fluctuating lake levels.

At the time when $P$. boisei and H. habilis visited the area, Olduvai was located in a tropical semi-arid climatic setting, and most of the time centered by a highly saline-alkaline paleo-Lake (Figure 2). During Bed I deposition, the lake was hydrologically closed and shallow and covered up an extension of $250 \mathrm{~km}^{2}$ (Hay, 1976; Hay and Kyser, 2001). This lake expanded and contracted regularly, probably driven by wet/dry climate cycles (Hay, 1976; Hover and Ashley, 2003). During UBII times (about 1.3 Ma), the perennial lake disappeared and was replaced by small ponds and marshlands (Hay, 1976). In addition to the saline lake, fresh-water areas were also identified at different localities such as HWK W and FLK N (Ashley et al., 2010; Hay, 1976; Liutkus and Ashley, 2002; etc.) (Figure 2).

But Olduvai Gorge is also known because it was one of the first paleoanthropological sites where researchers have conducted intensive research to better understand human activities and their effect on the landscape. One example is the 'hominin land use model' developed by Blumenschine and Peters under the frame of OLAPP. This model combines sampling of hominin activity traces over broad spatial scales, throughout exposed deposits of the Plio-Pleistocene Olduvai Basin with detailed paleoenvironmental analysis of the terrain, hydrology, and vegetation (Blumenschine and Peters, 1998; Peters and Blumenschine, 1995). The authors formulated predictions on the density and 

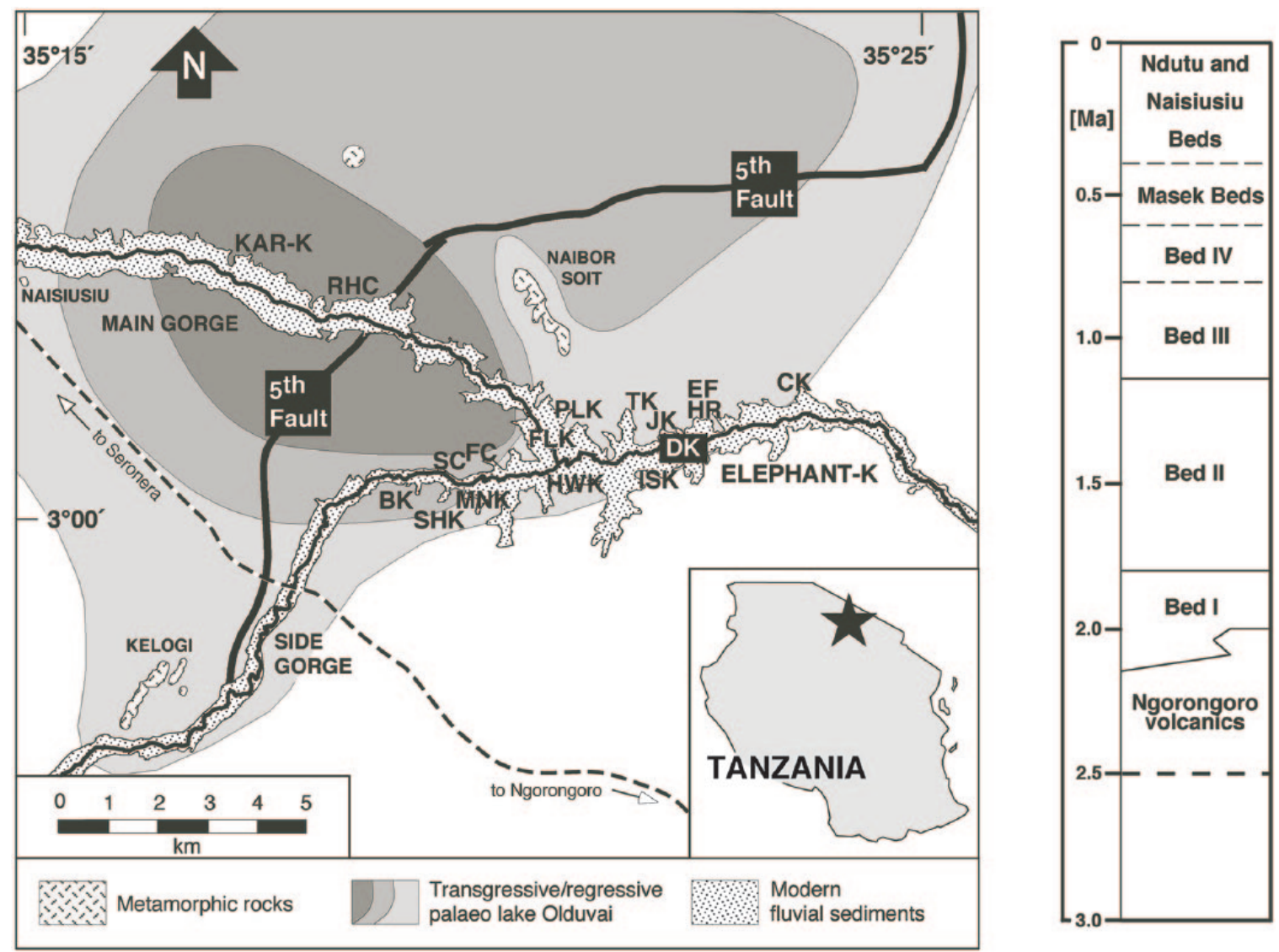

Figure 2. Plan of Olduvai Gorge (Tanzania), showing stratigraphic section and the location of important localities listed by Hay (1976).

composition of vertebrate fossil and stone artifact assemblages that could be recovered for each hypothesized paleolandscape facet throughout all the ancient lake. These predictions were based on a series of principles of ecological archaeology, and on two environmental variables, the landscape facet-specific cover abundance of trees and shrubs, and the degree of competition among carnivores and hominids for scavengeable carcass parts (Blumenschine and Peters, 1998; Peters and Blumenschine, 1995). Thereafter, OLAPP research has been based on this model.

\section{Vegetation at Olduvai}

In the last decades, studies addressed to reconstruct the vegetation at Olduvai Gorge have been undertaken on a regular basis and in parallel to the archaeological excavations. Previous studies based on the pollen spectra, carbon isotopes, and fauna provided a general picture of the paleoenvironment and vegetation showing a shift from more wooded vegetation cover during Middle and Upper Bed I time to more open vegetation by Uppermost Bed I (UMBI), to woodland mosaics in Lower Bed II (LBII) (Bonnefille, 1984; Kappelman, 1984; Kappelman et al., 1997; Sikes, 1994). Over this time, the landscape and vegetation would have been strongly influenced by the presence of the highly salinealkaline lake, which disappeared during Bed II times (Hay, 1976; Stanistreet, 2012).

Copeland (2007), following Peters and Blumenschine's (1995) 'hominin land use model', described the vegetation of LMBII, based on comparative analyses of modern analogous landscapes of Lake Manyara National Park, Serengeti National Park, and Ngorongoro Crater Conservation Area. For Copeland, a seasonal variation in plant food availability was of central importance to ranging patterns of hominins, since most plant foods were only seasonally available. Nevertheless, the mosaic nature of the area provided hominins with different food resources along the year within short distances. In any case, Copeland recognizes the difficulty for finding current equivalent models to those from the past, and thus these interpretations need to be sustained by archaeological identification of fossil plant remains (Copeland, 2007).

Later vegetation studies, conducted by the various teams working in the area (OLAPP and TOPPP), have been mostly based on phytoliths and macroplant fossil remains and have focused on Beds I and II (Albert and Bamford, 2012; Albert et al., 2006, 2009, 2014; Ashley et al., 2010; Bamford, 2012; Bamford et al., 2006, 2008; Barboni et al., 2010; etc.) (Figure 2). In particular, OLAPP studies, since 2001, have built on comparative studies with modern samples (plants and soils) from analogous ecosystems present today in the region. In addition to the sites studied by Copeland (Lake Manyara National Park, Serengeti National Park, and Ngorongoro Crater Conservation Area), other sites such as Lake Masek, Lake Ndutu, and Lake Eyasi have been added to the study (Albert et al., 2006, 2014; Bamford et al., 2006) (Figure 1).

Overall, the macroplant fossil and phytolith data show evidence that vegetation varied over small distances $(100-200 \mathrm{~m})$ and over relatively short periods of time. These results highlight the importance of understanding the nature of the variation in these local habitats/landscape facets in terms of hominin resources (Albert et al., 2006).

At FLK 22 and FLK NN localities (Figure 2) during the time that $P$. boisei and H. habilis visited the area (Upper Bed I - UBI), the OLAPP landscape reconstruction showed a topographic high point (the peninsula) carved out by a fluvial incision of the lake margin following a major lake regression (Blumenschine et al., $2012 b$ ). The vegetation results, according to fossil macroplants and phytoliths, indicated that trees and short grass/sedgelands were present in the open areas on the Peninsula, and a mixedspecies marshland with areas of open water was growing in the channel and wetland (Figure $3 \mathrm{a}-\mathrm{c}$ ). Barboni et al. (2010) also 

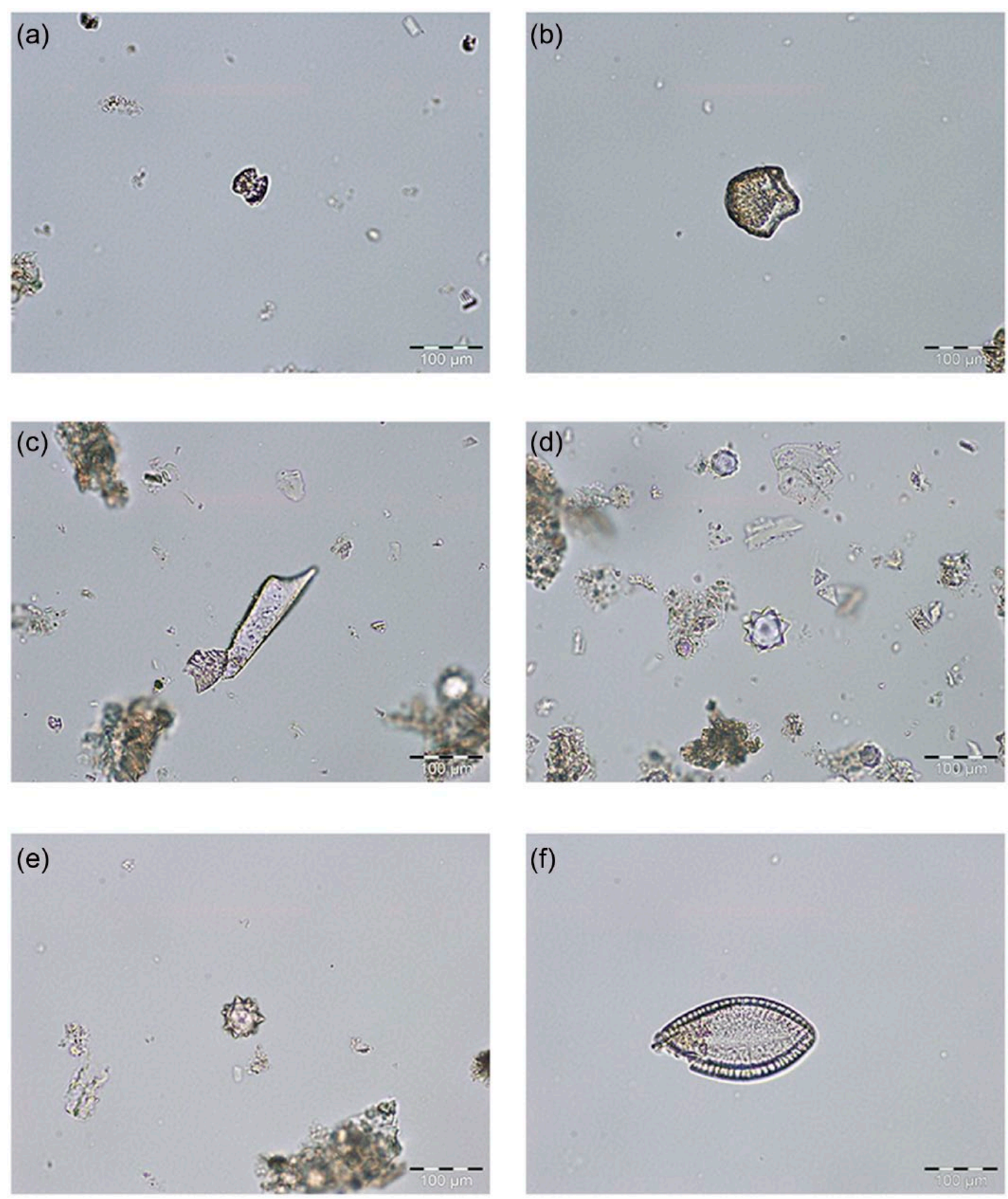

Figure 3. Microphotographs of phytoliths identified in palaeoanthropological samples from Olduvai Gorge. Pictures taken at 400x. (a) Short cell saddle type representative of $\mathrm{C} 4$ Chloroid grasses; (b) bulliform cells from grass leaves; (c) prickle characteristic of grasses; (d, e) spheroids echinate from palms; and ( $f$ ) diatom identified in association to palm phytoliths indicating water presence close to palms.

described the vegetation at FLK N and FLK Zinj as spatially heterogeneous with patches of dense woody vegetation (forest, woodland, or bushland) with scattered palm trees within a grassdominated biome similar to wooded grassland.

Phytolith and macroplant analyses have also been carried out at DK locality in Bed I, between basalt lava and Tuff IB. This study represents the oldest sedimentary interval analyzed for vegetation at Olduvai Gorge. The results have shown diverse vegetation, which includes grasses, probably sedges, very few palms, as well as woody plants, associated with a fresh-water pool (Albert et al., 2015).

In UMBI, Tuff IF, and LMBII, the combined study of phytoliths and macroplants at different localities showed that the eastern lake margin was sparsely vegetated by grassland associated with woody plants (Albert and Bamford, 2012;
Bamford et al., 2008). During the time of the deposition of the surges, vegetation was sparse near the lake but flourished close to the eastern fault scarp in the HWK compartment. During LMBII times, both compartments were well vegetated after lake regressions.

The identification of palm trees (through phytolith analyses) at various localities such as HWK EE, VEK, and FLK N is remarkable (Albert and Bamford, 2012; Albert et al., 2006, 2009; Barboni et al., 2010) (Figures 2 and 3d-e). At HWK EE, this palm presence was associated with diatoms, indicating the presence of fresh water (Albert et al., 2009) (Figure 3f). These results were consistent with those obtained by Hay (1976) and Ashley et al. (2010) who had also recognized the presence of fresh water at HWK E locality. At FLK N, palms were also associated with fresh-water springs although in lower amounts (Barboni et al., 2010). More 
recent studies by OLAPP have recognized phytoliths from palms at HWK W during Bed I times (personal observation).

Phytolith studies on contemporary levels to $H$. erectus are presently being conducted in the area by OGAP and TOPPP, and hopefully will shed more light on the resources available as well as on the activities related to food acquisition (De la Torre et al., 2012; Domínguez-Rodrigo et al., 2014).

\section{Hominin activities at Olduvai Gorge}

Tool production. Tools and other artifacts may provide evidence of early hominin behavior, interaction with their surrounding landscape, and cognitive knowledge. The best-preserved tools are made of stone, although it is probable that they might have also used other available raw material such as wood or bone, unpreserved in the archaeological record. The earliest stone tools recognized, so far, have been dated approximately to $2.5-2.6 \mathrm{Ma}$ at Gona (Ethiopia) (Semaw et al., 1997) and to 2.0 Ma in Kanjera (Kenya) (Ferraro et al., 2013; Plummer et al., 1999). This is known as Oldowan industry or Mode I, since it was at Olduvai Gorge when it was first studied.

Technologically, the Oldowan industry is simple and addressed to produce sharp edges. The type of tools includes choppers (one retouched side), chopping tools (two retouched sides), radial and polyhedral cores, retouched flakes, and so on. At Olduvai, the taphonomic examination of fossil bones along the years showed abundant cut marks and percussion notches, indicating that stone tools had been used to process carcasses (Blumenschine, 1995; Bunn, 1981; Domínguez-Rodrigo, 1997; Potts and Shipman, 1981; etc.).

In addition to the abundant presence of Oldowan tools, Olduvai Gorge is the site where the transition from the Oldowan to the Acheulean (or Mode II) (defined by the appearance of handaxes, i.e. large pointed stone tools with heavy duty edges, and related to H. erectus) was first documented, and where the archaeological evidence of this new Acheulean technology was first described (EFHR site, Leakey, 1971) (Figure 2).

The oldest Acheulean industry comes from Kokiselei West Turkana, 1.76 Ma ago (Lepre et al., 2011). This chronology is nevertheless late, in relation to $H$. erectus earlier remains (dated at least 1.8 Ma and possibly 1.9 Ma) (Anton, 2003; Feibel et al., 1989). In view of this later appearance, it is probable that $H$. erectus were still using Oldowan technology for thousands of years before the first Acheulean industry appeared (Spoor et al., 2007).

At Olduvai Gorge, the Acheulean industry is dated to $1.6 \mathrm{Ma}$ (De la Torre et al., 2012; Leakey, 1971). Conversely, the earliest remains of $H$. erectus $(\mathrm{OH} 9)$ were located in UBII and dated 1.2 Ma (Leakey, 1971; Rightmire, 1979) (Figure 2). Other H. erectus remains $(\mathrm{OH} 28,22,51$, and 12) were uncovered in Beds III/IV and were dated, approximately 1.1 Ma (Tamrat et al., 1995). More recently, Domínguez-Rodrigo et al. (2012) uncovered remains of a 2-year old child (OH81) in UBII. Due to the fragmentary nature of these remains, they cannot be reliably assigned to a particular species. However, their association with stone tools, butchered bones, and their stratigraphic position make the authors conjecture that these remains may well correspond to H. erectus.

In relation to the raw material used to produce the stone tools, Olduvai hominins were using Precambrian quartzite from Naibor Soit and Naisiusiu Hill outcrops, as well as different volcanic material such as Phonolite from the Engelosin volcanic neck, basalt and trachyandesite from Lemagrut, nephelinite from Sadiman volcano, and trachyte (Hay, 1976; Leakey, 1971). All this material was available at Olduvai Gorge and within walking distance. The results obtained by Blumenschine et al. (2012a) on the landscape distribution of Oldowan stone artifact assemblages during LMBII on the eastern Olduvai basin indicate a local exploitation of the raw material, both volcanic and quartzite, by the populations occupying the area (Blumenschine et al., 2012a).

Hence, Olduvai hominins would have exploited different types of local raw material to produce stone tools for a variety of purposes such as the acquisition and processing of meat, according to the archeological evidence. The use of the same stone tools to acquire plant products for various uses is also plausible. These stone tools would have been used by a same group of hominins in a variety of ecological settings (Hay, 1976). Questions related to raw material preference for producing different tools need to be further developed (Reti, 2009).

Hunting/scavenging and gathering. It is commonly assumed that $H$. erectus was more predatory than $H$. habilis. The new anatomical traits observed in $H$. erectus, which included a more humanlike brain and a better adapted body to long-distance running, have been traditionally associated with a change in diet with the incorporation of animal products (Shipman and Walker, 1989). Taking as an example the 2-year old hominin (OH81) from Olduvai, Domínguez-Rodrigo et al. (2012) argue that at 1.5 Ma hominins were already adapted to a diet, which included a regular consumption of meat.

Regular meat intake implies a change in dietary habits to meet the needs for proteins and energy intake to manage increasing metabolic costs (Aiello and Wheeler, 1995). Occasional hunting, such as chimpanzees do, would not cover these needs, and thus, meat should be obtained either by an increase in the hunting activities, or scavenging, or both.

The way these early hominins were acquiring this meat, either through scavenging or hunting or both, has been the cause of arduous debates, particularly at Olduvai Gorge along the years of research.

Multiple localities of the gorge show evidence of in situ butchered mammal remains, ranging in size from hedgehogs to elephants. They are associated with large numbers of stone tools (Blumenschine and Pobiner, 2006; Domínguez-Rodrigo et al., 2007, and references therein).

As above-mentioned, Leakey (1971) interpreted FLK Zinj and other sites such as DK in Bed I as living floors and assumed that at that time hominins had primary access to meat through hunting. This interpretation, however, was questioned by Binford (1981), who reinterpreted these sites as carnivore-made accumulations, and situated hominins as marginal scavengers. Nowadays, and despite the introduction of new techniques, such as the analyses of butchery marks, which include the identification of cut and percussion marks in bones, this issue has not yet reached consensus, and both scenarios, scavenging and hunting, have been defended (Blumenschine, 1995; Domínguez-Rodrigo et al., 2007, and references therein).

The hunting of large mammals as regular practice as well as active scavenging (through confrontation with other predators) would strengthen social bonds to facilitate success. In addition, hunting would also have a direct impact on animal behavior and its relationship with the ecosystem, situating these hominins in direct competition with large carnivores while remaining dangerous predators as well. Another important change in relation to other wildlife meat acquisition relates to the use of tools to obtain the meat, and the possibility of accessing animals that were larger than hominins themselves. The degree of the dependence on meat consumption and its availability will relate, thus, to the technological capacity and will influence the ranging activities.

Besides meat consumption, plants also played an important role in early hominins diet. However, our knowledge on their abilities to collect plant foods is still very limited, despite the fact that plant foods clearly provided a major source of energy (Milton, 2000), as humans need large amounts of carbohydrates (Wrangham, 2009). Furthermore, all modern hunting-gathering 
societies consume plants to a certain degree, and in some cases, this can be as much as $60-70 \%$ of their diet (Zihlman and Tanner, 1978). One example is the !Kung from southern Africa whose diet consists of both animal and plant foods with plants representing around $67 \%$ of the total dietary intake (Milton, 2000). Similarly, the diet of the Hadza hunter-gatherers of Tanzania comprises over $60 \%$ wild plants even though they refer to themselves as hunters (Milton, 2000).

Plant gathering will depend on the ability to carry bundles of food, memory to return to the locations where wild staples are found, special tools for digging when collecting underground storage organs (USOs), geophytes, and so on (Figure 4a, b). At the same time, gathering implies a certain social organization since it presupposes the existence of 'base camps' where the collected food is brought and shared. For modern hunter-gatherers, gathering is critical since hunters often return empty-handed, in which case the group must rely entirely on gathered foods. According to Milton (2000), gathering for these societies frequently depends on one or a very small number of dependable wild staples which provide much of their energy needs. The question is, did early hominins have the cognitive capacity for gathering? What breakthroughs in technology or changes in social context enabled gathering to develop (Wrangham, 2009)?

Other food resources available to early hominins were honey, anthropods, mollusks, and other invertebrates. Honey is the highest-calorie food in nature and does not require cooking (Wrangham et al., 1999). Also, honey is regularly exploited nowadays by the modern Hadza hunter-gatherer populations from the area (personal observation). Other sources of food products are anthropods, mollusks, and other invertebrates, which are also of higher energetic quality than meat (Wrangham et al., 1999). Mollusks, bird, and fish are usually available in aquatic habitats. For example, a study in Kenya has shown that at least some early hominins included aquatic species in their diet (Braun et al., 2010).

The studies conducted at Olduvai, at FLK N locality where $P$. boisei was recovered (Figure 2), indicated that this area was part of a broad and ecologically diverse and productive land surface, which was extensively used by hominins mostly on the Peninsula and Wetland Edge (Blumenschine et al., 2012a). Nevertheless, this area was also visited by large carnivores and was thus a dangerous place to be used as base camp and for social activities. Most probably, hominins during UMBI and LMBII would visit this area at regular intervals in search of fresh water, plants, and aquatic animals. The sedges would have provided edible rootstock, and perhaps some of the woody herbs, shrubs, or trees produced edible fruits or seeds in addition to shade and shelter (Albert and Bamford, 2012). The diverse, closed woodland indicated by rodents suggests that safer sites for sleeping and fuller range of activities existed elsewhere, more likely further inland (Blumenschine et al., 2012a). Other areas such as Long K fault, where there is a high artifact density, may have provided safer areas where to carry out different activities such as processing of carcasses acquired in more open and dangerous locales (Blumenschine et al., 2012a).

At HWK E during LMBII and at HWK W during Bed I (Figure 2 ), the abundant presence of palms associated with fresh-water sources would have provided hominins with water, aquatic animals, and possible fruits from the palms among other plants. One local modern palm analogue is Phoenix reclinata (wild date palm) abundant in current savannah environments usually related to fresh-water areas such as riverbanks or swamps (Figure 5a, b). Modern hunter-gatherer groups like those occupying the Tana River district of northeastern Kenya as well as the Tana River crested mangabey (Cercocebus galeritus galeritus) exploit the fruits and the seeds of this plant (Kinnaird, 1995). The fruits are available between April-May and September-October. Hence, palm fruits might be as well a food source for hominins during the
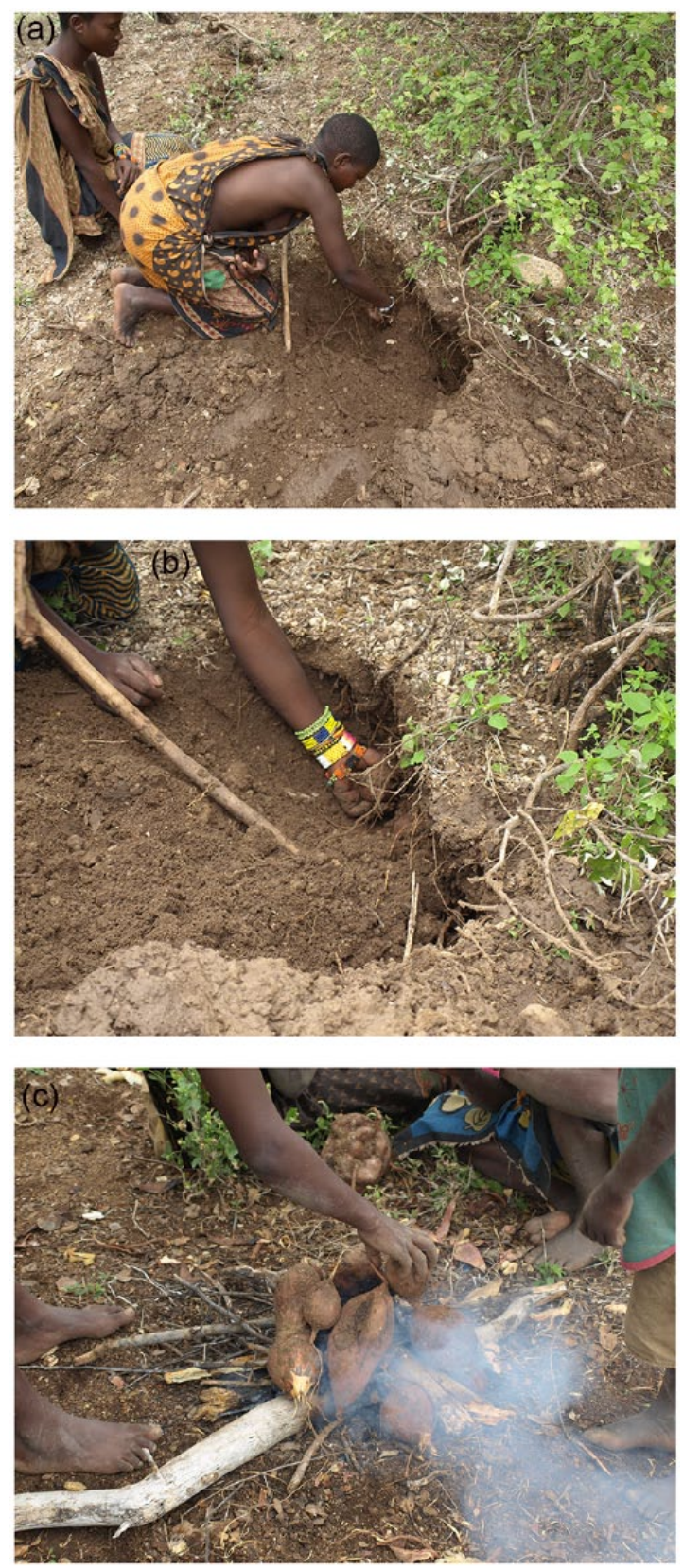

Figure 4. (a) Picture of Hazda women gathering USO. Image taken in April 2012 at Lake Eyasi; (b) close-up view and (c) roasting of USOs before consumption.

rainy season when these fruits are available (Albert and Esteban, in press). This is especially true for $H$. habilis populations, whose isotopic and dental microwear results indicate that they had a softer diet than $H$. erectus (Martínez et al., 2006). Other studies conducted on $P$. boisei indicate a diet consisting mostly of $\mathrm{C}_{4}$ plants, which included large quantities of low-quality vegetation, mostly grasses and sedges (Cerling et al., 2011).

Vegetation studies on contemporary levels to $H$. erectus are presently being conducted and hopefully will shed light on the resources available as well as on the activities related to food acquisition. In any case, we hypothesize that the anatomical modifications of $H$. erectus, better adapted to savannah environments, would have led to a series of changes in behavior and interaction with the surrounding landscape. These might well include the acquisition, with the help of tools, of less accessible resources such as geophites. Dental microwear results of $H$. erectus teeth indicate that these homo ate, at least occasionally, more brittle or tough items than other fossil hominins (Ungar et al., 2006). 

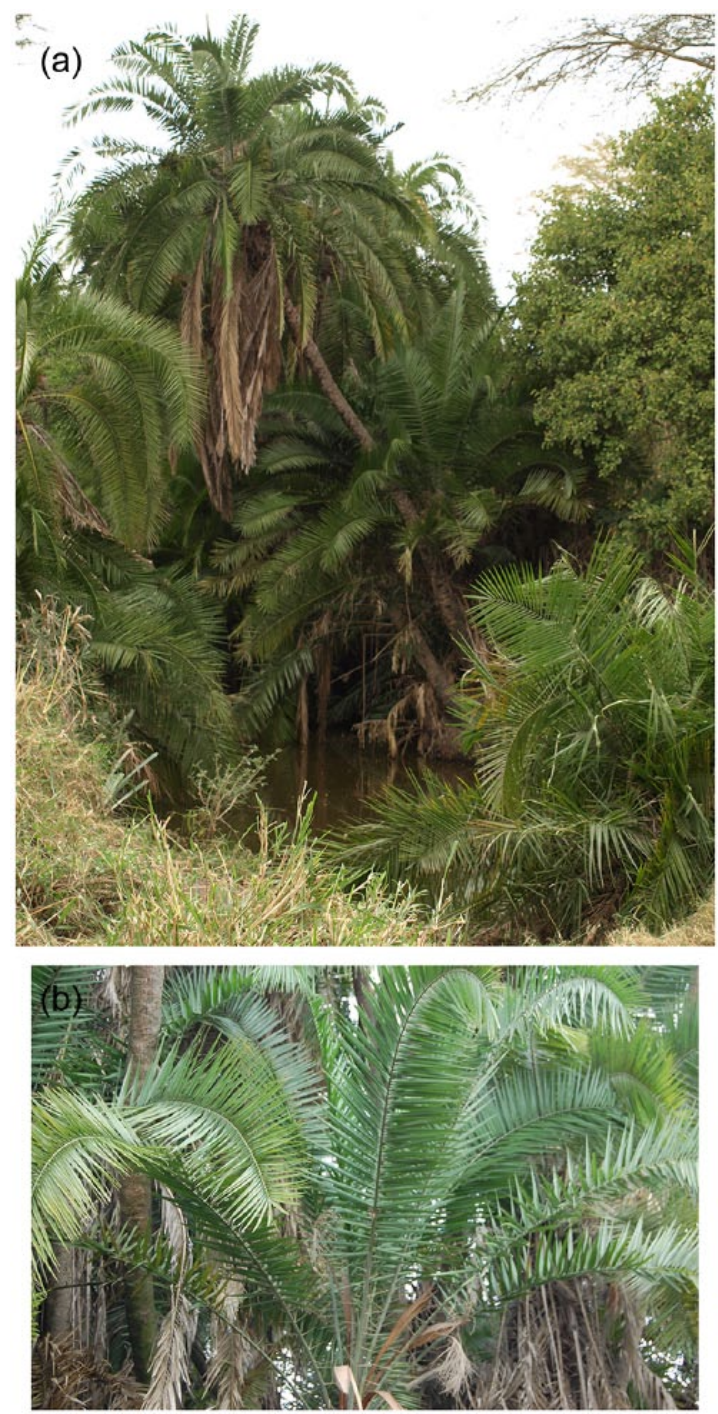

Figure 5. (a, b) Images of Phoenix reclinata palms. Image taken at Serengeti National Park in July 2012.

To summarize, hominins at Olduvai would have conducted a local and intensive exploitation of a varied type of resources. The mosaic landscape within short-distance walking would have provided them with different resources, such as fresh water, edible plants (tubers, roots, bulbs, fruits, seeds, etc.), honey, aquatic animals, and meat. Raw material supplies to produce the stone tools were also available in the vicinity. Nevertheless, the climatic conditions with distinctive wet and dry seasons (Cerling and Hay, 1986) meant that some of these food resources were not always available, mainly during the dry season (honey, part of the fauna, fruits and seeds, etc.), and thus would have forced hominins to search for alternative resources implying a change in diet and ranging activities, based on seasonality.

Finally, the area would have also provided $P$. boisei and $H$. habilis with shelter, such as trees, from other predators. H. Erectus, being non-arboreal, would have required alternative sleeping sites, possibly on the ground, and would have needed fire for protection (Wrangham, 2009; Wrangham and Carmody, 2010; Wrangham et al., 1999).

Anthropogenic fire. In 1999, Richard Wrangham and colleagues formulated the cooking hypothesis, which they have developed further (Gowlett and Wrangham, 2013; Wrangham, 2009; etc.). This hypothesis was based on the fact that the anatomy of $H$. erectus with its small jaws and teeth was poorly adapted for eating tough raw meat and suggested that they might have developed the ability to use fire for cooking both meat and plant products (Gowlett and Wrangham, 2013). Cooked meat provides an energetic benefit over the consumption of raw meat (Boback et al., 2007), and cooking increases the digestibility of USOs, which are thought to have been an important part of their diet (Figure 4c). The possibility that $H$. erectus had the ability to cook implies a new capability, which has important and visible effects on the landscape. We are referring to the ability to make fire.

And this leads us to address the issue of the use and control of fire, which is one of the most appealing aspects regarding hominin activities and with a greater impact on the environment, as noted by Foley et al. (2013) and Glickson (2013).

Use of fire is one of the greatest human achievements and was one of the most important steps in our evolution at a physical, social, and cognitive level (Perlès, 1977). Early uses of fire may have included heating, protection from predators, as well as an offensive weapon to increase the capabilities for hunting bigger and better preys, illumination expanding the time to work and carry out social activities as well as to strengthen social bonds, and cooking (Oakley, 1970).

Evidence for the controlled use of fire by early human populations has conventionally derived from hearths or constructed combustion features sensu Roebroeks and Villa (2011). These features may be split into (1) the container which includes the hearth, reddened areas, burnt clay, and (2) the contents, namely, the material used for the fuel (i.e. wood, bones, dung) and other burnt remains that may include bones, stone tools, shells, seeds, and tubers.

Some of the best-known claims for fire-use in African openair sites come from the Lower Paleolithic sites of Gadeb 8E (Ethiopia) (Barbetti, 1986), Koobi Fora FxJj 20 East (Bellomo, 1994; Rowlett, 2000), and Chesowanja 1/6E (Kenya) (Gowlett et al., 1981).

However, one of the main problems with identifying constructed combustion features in open-air sites is that they are exposed to external factors such as wind, water, animal activity, erosion, and so on (e.g. Mallol et al., 2007). Also, diagenesis may have affected the preservation of the remains. As a result, none of these earliest examples have been exempt from controversy. Detractors of early use of fire argue that the presence of burned archaeological material (bones, stone tools, etc.) or reddened areas by themselves are not sufficient proof of human control of fire, and they interpret this evidence as the result of natural wildfires or, at the most, representative of opportunistic use of natural fires (Roebroeks and Villa, 2011).

Undisputed hearths or structured combustion derives mostly from caves and shelter contexts. One of the earliest examples is found at Wonderwerk Cave, stratum 10 (South Africa) dated 1.0 Ma (Berna et al., 2012). Nevertheless, regular use of fire is not recorded until ca. 400-500 ka (Rolland, 2004).

Whereas use of controlled fires or hearths may have low impact on the landscape, anthropogenic burning may have affected vegetation patterns, fauna, and climate at least on a regional scale. For example, Schulz (1993) argued that anthropogenic fire, coupled with domestication of livestock, is the main reason for the expansion of the Sahel and the increase in desertification rates, which have taken place in the past thousand years.

The use of anthropogenic fire by Native Australian populations, as 'environmental tool', also had important implications for the landscape (Bowman, 1998). Low intensity fires remove the woody understory and allow grasses and other herbaceous plants to flourish, attracting herbivores to the area. Fire also promotes fire-tolerant plants at the expense of those which are not. The exact time when these Native Australian populations began to use fire remains unclear, being the cause of several debates. For example, Kershaw (1986) suggests that these populations probably caused the increase of burning observed in Northeast Australia about $38,000 \mathrm{ka}$. 
However, anthropogenic fire is difficult to distinguish from natural wildfires. Bird and Cali (1998) studied the elemental carbon abundance from marine sediments on the Sierra Leone rise, and inferred that fire incidence in the region was low until 400,000 ka. After that time, there is a high increase in fire frequency, which the authors relate to anthropogenic action since they occurred during the time global climate was changing from interglacial to glacial. For these authors, anthropogenic fire can be detected by their limited spatial extent and increased frequency relative to the immediate vicinity.

At Olduvai Gorge, despite Pante's observations for Beds III and IV of burned bones (Pante, 2010) (Figure 2), no systematic studies have been conducted yet on the Acheulean levels to detect possible anthropogenic burning. From our team, we have undertaken a new project addressed to answer these questions. Using different methodological approaches such as Fourier Transformed Infrared Spectrometry (FTIR), x-ray diffraction (XRD), Total Organic Compound (TOC), and so on, we expect to find archaeological evidence of $H$. erectus fire-use as hypothesized by Wrangham et al. (1999).

\section{Discussion}

Human activities have affected landscape, vegetation, and other wildlife. The beginning of Holocene, with the implementation of agricultural and herding practices, represents a turning point in human history. The causes, though, need to be sought back in time, and related to the learning and accumulation of knowledge associated with an increasing control on the landscape and the acquisition of resources.

Early hominin activities were clearly aimed at improving the acquisition of resources, particularly those related to diet. This early diet was probably similar to that of modern chimpanzees: omnivores, including large quantities of fruits, leaves, flowers, bark, insects, and meat (Andrews and Martin, 1991). However, the difference relies not so much on the purpose of acquiring these resources but on the way to acquire them, through a change in cognitive-behavioral strategies, which allowed the acquisition of a more varied source of resources and improved their chances for survival.

At Olduvai Gorge, the very first impact on the landscape as a result of strictly human actions can only be placed at a local-scale influence, and affecting mostly the vegetation and fauna living in the close vicinity areas. The extent of this impact, however, is far from clear. A priori, the mosaic landscapes within short-distance walking would have provided hominins with abundant and varied resources, mostly during the rainy season (palm and other tree fruits, seeds, meat, honey, etc.) as well as aquatic animals, attested by the identification of fresh-water sources. Conversely, the dry season represents a period of food scarcity and would have forced hominins to modify their collecting strategies and to search for alternative and less accessible resources (i.e. marrow), and/or to shift to fallback products (with lower nutritional values) (Alberts et al., 2005). The choice to exhaust the resources in certain areas or to move to new ones before that will have to be related to the size of the population and other social and/or cultural causes. Tool production, hunting-scavenging/gathering, and fire-making surely had some impact on the ecosystem, although probably at a low level and always depending on the intensity of these activities. The use of mathematical models applied to this area may help in shedding more light on human impact on the landscape.

With $H$. erectus, the different exploitation of resources would have had a higher impact on the ecosystem. The drier climatic conditions present at Olduvai, with the disappearance of the lake and the expansion of savannah landscape, would have forced these non-arboreal populations to increase their group size, in order to defend themselves from other predators, as observed in other primates (Hill and Lee, 1998). These larger groups would increase the need for resources and for a higher exploitation of the landscape, including the production of stone tools and the incorporation of new food products (brittle and/or tougher such as anthropods or geophites) according to dental microwear results (Ungar et al., 2006). Probably, the acquisition of food, and of raw materials to produce tools to acquire food, was still the main motivation to obtain resources. But it is also possible that raw material acquisition was related to producing weapons to defend themselves from other predators or hominins. The abundant presence of medicinal plants noted in this region may have driven hominins to use plants for medical purposes in addition to diet (Medina, 2015).

The impact of fire would be especially high with the use of anthropogenic burning and its capacity to modify the vegetation. At Olduvai Gorge, the identification of burned bones might point to the use of fire during Beds III/IV. We hope that the new OLAPP fire-project may help to shed more light on the initial moments when hominins began to use fire. Anthropogenic burning may have had strong implications related to changes in vegetation toward more fire-tolerant plants, and generating more open landscapes and grasslands. In relation to fauna, fire may have played an important role in the extinction and/or migration of some species because of the transformations in habitat conditions (Roberts et al., 2001). The degree of impact would not yet be significant but would point at early humans as precursors of the actions that would change the earth in the times-to-come.

Certainly, more environmental archaeology and environmental anthropology need to be carried out in order to improve our knowledge on this aspect. Human impact on earth is unavoidable, and thus, solutions need to be sought from our past experience on environmental knowledge.

Early hominin activities during the time P. boisei, H. habilis, and $H$. erectus were visiting Olduvai were already markedly distinctive from those of other wildlife. These new activities would have had a varying impact on the surrounding landscape depending on the type and intensity in which they were carried out.

In order to better comprehend those initial moments when hominins began the long-learning process to Holocene, we firmly believe that the term Anthropocene should be extended back in time to include these early cognitive-behavioral strategies and their impact on the landscape. Thus, the term paleoanthropocene or early Anthropocene, as suggested by Foley et al. (2013) and Glickson (2013), respectively, may well be applied to this early period.

\section{Acknowledgements}

We thank COSTECH (Tanzania Commissions for Science and Technology), TAWIRI (Tanzania Wildlife Research Inst), TANAPA (Tanzania National Parks), and the Department of Antiquities, Tanzania, for permission to carry out research at the Serengeti National Park, Lake Manyara, and Lake Eyasi as well as at Olduvai Gorge, and members of OLAPP for useful discussions. Finally, we would also thank reviewers for their suggestions and comments which have helped to improve this manuscript. Research material in relation to plant vegetation studies can be retrieved from http://www.phytcore.org.

\section{Funding}

Spanish financial support came from the Spanish Ministry of Science and Innovation (HAR2010-15967 and HAR2013-42054-P) as well as from AGAUR from the Catalan Government SGR20091418 for GEPEG and SGR2014-845 for ERAAUB.

\section{References}

Aiello LC and Wheeler P (1995) The expensive tissue hypothesis: The brain and digestive system in human and primate evolution. Current Anthropology 36: 199-221. 
Albert RM and Bamford MK (2012) Vegetation during uppermost Bed I and deposition of Tuff IF at Olduvai Gorge, Tanzania, based on phytoliths and plant remains. Journal of Human Evolution 63(2): 342-350.

Albert RM and Esteban I (2015) What early human populations ate? The use of phytoliths for identifying plant remains in the archaeological record. In: Hardy $\mathrm{K}$ and Kubiak Martens L (eds) Wild Harvest: Plants in the Homin and Pre-Agrarian Human Worlds. Oxford: Oxbow Books.

Albert RM, Bamford MK and Cabanes D (2006) Taphonomy of phytoliths and macroplants in different soils from Olduvai Gorge, Tanzania: Application to Plio-Pleistocene palaeoanthropological samples. Quaternary International 148: 78-94.

Albert RM, Bamford MK and Cabanes D (2009) Palaeoecological significance of palms at Olduvai Gorge, Tanzania based on phytolith remains. Quaternary International 193: 41-48.

Albert RM, Bamford MK and Esteban I (2014) Reconstruction of ancient palm vegetation landscapes using a phytolith approach. Quaternary International. Epub ahead of print 26 July. DOI: 10.1016/j.quaint.2014.06.067.

Albert RM, Bamford MK, Stanistreet I et al. (2015) Vegetation landscape at DK locality, Olduvai Gorge, Tanzania. Palaeogeography, Palaeoclimatology, Palaeoecology 426: 34-45.

Alberts SC, Hollister-Smith JA, Mututua RS et al. (2005) Seasonality and long-term change in a savanna environment. In: Brockman DK and Van Schaik P (eds) Seasonality in Primates: Studies of Living and Extinct Human and Non-Human Primates. Cambridge: Cambridge University Press, pp. 158-195.

Andrews P and Martin L (1991) Hominoid dietary evolution. Philosophical Transactions of the Royal Society of London, Series B: Biological Sciences 334: 199-209.

Anton S (2003) Natural history of Homo erectus. Yearbook of Physical Anthropology 46: 126-170.

Ashley GM, Barboni D, Domínguez-Rodrigo M et al. (2010) Paleoenvironmental and paleoecological reconstruction of a freshwater oasis in savannah grassland at FLK North, Olduvai Gorge, Tanzania. Quaternary Research 74: 333-343.

Bamford M (2012) Fossil sedges, macroplants, and roots from Olduvai Gorge, Tanzania. Journal of Human Evolution 63: 351-363.

Bamford MK, Albert RM and Cabanes D (2006) Plio-Pleistocene macroplant fossil remains and phytoliths from Lowermost Bed II in the eastern paleolake margin of Olduvai Gorge, Tanzania. Quaternary International 148: 95-112.

Bamford MK, Stanistreet IG, Stollhofen H et al. (2008) Late Pliocene grassland from Olduvai Gorge, Tanzania. Palaeogeography, Palaeoclimatology, Palaeoecology 257: 280-296.

Barbetti M (1986) Traces of fire in the archaeological record before one million years ago. Journal of Human Evolution 15: 771-781.

Barboni D, Ashley G, Domínguez-Rodrigo M et al. (2010) Phytoliths infer locally dense and heterogeneous paleovegetation at FLK North and surrounding localities during upper Bed I time, Olduvai Gorge, Tanzania. Quaternary Research 74: 344-354.

Bar-Yosef O and Belfer-Cohen A (2002) Facing environmental crisis: Societal and cultural changes at the transition from the Younger Dryas to the Holocene in the Levant. In: Cappers RTJ and Bottema S (eds) The Dawn of Farming in the Near East. Studies in Early Near Eastern Production, Subsistence, and Environment. 6th Edition. Berlin: Ex Oriente, pp. 55-66.

Bellomo R (1994) Methods of determining early hominid behavioral activities associated with the controlled use of fire at FxJj 20 Main, Koobi Fora, Kenya. Journal of Human Evolution 27: 173-195.

Berna F, Goldberg P, Horwitz LK et al. (2012) Microstratigraphic evidence of in situ fire in the Acheulean strata of Wonderwerk
Cave, Northern Cape province, South Africa. Proceedings of the National Academy of Sciences 109(20): 7593-7594.

Binford LR (1981) Bones: Ancient Men, Modern Myths. New York: Academic Press.

Bird MI and Cali JA (1998) A million-year record of fire in subSaharan Africa. Nature 394: 767-769.

Blumenschine RJ (1995) Percussion marks, tooth marks and the experimental determinations of the timing of hominid and carnivore access to long bones at FLK Zinjanthropus, Olduvai Gorge, Tanzania. Journal of Human Evolution 29: 21-51.

Blumenschine RJ and Peters CR (1998) Archaeological predictions for hominid land use in the Palaeo-Olduvai Basin, Tanzania, during lowermost Bed II times. Journal of Human Evolution 34: 565-607.

Blumenschine RJ and Pobiner BL (2006) Zooarchaeology and the ecology of Oldowan hominin carnivory. In: Ungar P (ed.) Early Hominin Diets: The Known, the Unknown and the Unknowable. Oxford: Oxford University Press, pp. 167-190.

Blumenschine RJ, Masao FT, Stollhofen H et al. (2012a) Landscape distribution of Oldowan stone artifact assemblages across the fault compartments of the eastern Olduvai Lake Basin during early lowermost Bed II times. Journal of Human Evolution 63(2): 384-394.

Blumenschine RJ, Stanistreet IG, Njau JK et al. (2012b) Environments and activity traces of hominids across the FLK Peninsula during Zinjanthropus times (1.84 Ma), Olduvai Gorge, Tanzania. Journal of Human Evolution 63(2): 364-383.

Boback SM, Cox CL, Ott BD et al. (2007) Cooking and grinding reduces the cost of meat digestion. Comparative Biochemistry and Physiology Part A: Molecular \& Integrative Physiology 148: 651-656.

Bonnefille R (1984) Palynological research at Olduvai Gorge. National Geographic Society Research Reports 17: 227243.

Bowman DMJS (1998) Tansley review no. 101: The impact of Aboriginal landscape burning on the Australian biota. New Phytologist 140: 385-410.

Braun DR, Harris JW, Levin NE et al. (2010) Early hominin diet included diverse terrestrial and aquatic animals $1.95 \mathrm{Ma}$ in East Turkana, Kenya. Proceedings of the National Academy of Sciences 107(22): 10002-10007.

Bunn HT (1981) Archaeological evidence for meat-eating by Plio-Pleistocene hominids from Koobi Fora and Olduvai Gorge. Nature 291: 574-577.

Cerling TE and Hay RL (1986) An isotopic study of paleosol carbonates from Olduvai Gorge. Quaternary Research 25: 63-78.

Cerling TE, Mbua F, Kirera F et al. (2011) Diet of Paranthropus boisei in the early Pleistocene of East Africa. Proceedings of the National Academy of Sciences 28(23): 9337-9341.

Copeland SR (2007) Vegetation and plant food reconstruction of lowermost Bed II, Olduvai Gorge, using modern analogs. Journal of Human Evolution 53: 146-175.

Crutzen PJ (2002) Geology of mankind. Nature 415: 23.

Crutzen PJ and Stoermer EF (2000) The Anthropocene. Global Change Newsletter 41: 17-18.

De la Torre I, McHenry L, Njau J et al. (2012) The origins of the Acheulean at Olduvai Gorge (Tanzania): A New Paleoanthropological Project in East Africa. Archaeology International 15: 89-98.

Domínguez-Rodrigo M (1997) Meat-eating by early hominids at the FLK 22 Zinjanthropus site, Olduvai Gorge, Tanzania: An experimental approach using cut mark data. Journal of Human Evolution 33: 669-690.

Domínguez-Rodrigo M, Barba R and Egeland CP (2007) Deconstructing Olduvai. New York: Springer. 
Domínguez-Rodrigo M, Diez-Martin F, Mabulla A et al. (2014) The evolution of hominin behavior during the Oldowan-Acheulian transition: Recent evidence from Olduvai Gorge and Peninj. Quaternary International 322-323: 1-6.

Domínguez-Rodrigo M, Pickering TR, Diez-Martín F et al. (2012) Earliest porotic hyperostosis on a 1.5-million-year-old hominin, Olduvai Gorge, Tanzania. PLoS ONE. Epub ahead of print 3 October. DOI: 10.1371/journal.pone.0046414.

Feibel CS, Brown FH and McDougall I (1989) Stratigraphic context of fossil hominids from the Omo group deposits: Northern Turkana Basin, Kenya and Ethiopia. American Journal of Physical Anthropology 78: 595-622.

Ferraro JV, Plummer TW, Pobiner BL et al. (2013) Earliest archaeological evidence of persistent hominin carnivory. PLOS ONE 8(4): e62174.

Foley SF, Gronenborn D, Andreade MO et al. (2013) The Palaeoanthropocene - The beginnings of anthropogenic environmental change. Anthropocene 3: 83-88.

Glickson AY (2013) Fire and human evolution: The deep-time blueprints of the Anthropocene. Anthropocene 3: 89-92.

Gowlett JAJ and Wrangham RW (2013) Earliest fire in Africa: Towards the convergence of archaeological evidence and the cooking hypothesis. Azania: Archaeological Research in Africa 48(1): 5-30.

Gowlett JAJ, Harris JWK, Walton D et al. (1981) Early archaeological sites, hominid remains and traces of fire from Chesowanja, Kenya. Nature 294: 125-129.

Hay RL (1976) Geology of the Olduvai Gorge. Berkeley, CA: University of California Press.

Hay RL and Kyser TK (2001) Chemical sedimentology and paleoenvironmental history of Lake Olduvai, a Pliocene lake in northern Tanzania. Geological Society of America Bulletin 113: $1510-1521$.

Hill RA and Lee PC (1998) Predation pressure as an influence on group size in Cercopithecoid primates: Implications for social structure. Journal of Zoology 245: 447-456.

Hover VC and Ashley GM (2003) Geochemical signatures of paleodepositional and diagenetic environments: A STEM/ AEM study of authigenic clay minerals from an arid rift basin, Olduvai Gorge, Tanzania. Clays and Clay Minerals 51: 231-251.

Kappelman J (1984) Plio-Pleistocene environments of Bed I and Lower Bed II, Olduvai Gorge, Tanzania. Palaeogeography, Palaeoclimatology, Palaeoecology 48: 171-196.

Kappelman J, Plummer T, Bishop L et al. (1997) Bovids as indicators of Plio-Pleistocene palaeoenvironments in East Africa. Journal of Human Evolution 32: 229-256.

Kershaw P (1986) The last two glacial-interglacial cycles from Northeastern Australia: Implications for climatic change and Aboriginal burning. Nature 322: 47-49.

Kinnaird MF (1995) Competition for a forest palm: Use of Phoenix reclinata by human and nonhuman primates. Conservation Biology 6: 101-107.

Leakey LSB (1961) New finds at Olduvai Gorge. Nature 189: 649-650.

Leakey MD (1971) Olduvai Gorge: Excavations in Beds I and II, 1960-1963. Cambridge: Cambridge University Press.

Lepre CJ, Roche H, Kent DV et al. (2011) An earlier origin for the Acheulian. Nature 477: 82-85.

Liutkus C and Ashley G (2002) Facies model of a semiarid freshwater wetland, Olduvai Gorge, Tanzania. Journal of Sedimentary Research 73: 691-705.

McHenry LJ, Mollel GF and Swisher CC III (2008) Compositional and textural correlations between Olduvai Gorge Bed I tephra and volcanic sources in the Ngorongoro Volcanic Highlands, Tanzania. Quaternary International 178: 306-319.
Mallol C, Marlowe FW, Wood BM et al. (2007) Earth, wind, and fire: Ethnoarchaeological signals of Hadza fires. Journal of Archaeological Science 34: 2035-2052.

Martínez L, Pérez-Pérez A and Turbón D (2006) Nutrition in ancient hominids. International Congress Series 1296: 16-22.

Medina V (2015) Dieta humana y subsistencia en el margen occidental del Lago Natrón (Tanzania): Los recursos alimentarios en el registro Pli-pleistocénico de Peninj. PhD Thesis, Universitat de Barcelona.

Milton K (2000) Hunter-gatherer diets: A different perspective. American Journal of Clinical Nutrition 71(3): 665-667.

Oakley KP (1970) On man's use of fire, with comments on toolmaking and hunting. In: Washburn SL (ed.) Social Life of Early Man. Chicago, IL: Aldine Publishing Company, pp. 176-193.

Pante MC (2010) The larger mammal fossil assemblages from Beds III and IV, Olduvai Gorge Tanzania: Implications for the feeding behavior of Homo erectus. PhD Thesis, Rutgers University.

Perlès C (1977) Préhistoire du feu. Paris: Masson.

Peters CR and Blumenschine RJ (1995) Landscape perspectives on possible land use patterns for Early Pleistocene hominids in the Olduvai Basin, Tanzania. Journal of Human Evolution 29: 321-362.

Plummer T, Bishop LC, Ditchfield P et al. (1999) Research on Late Pliocene Oldowan sites at Kanjera South, Kenya. Journal of Human Evolution 36: 151-170.

Potts R and Shipman P (1981) Cutmarks made by stone tools on bones from Olduvai Gorge, Tanzania. Nature 291: $577-580$.

Reti JS (2009) Quantified Oldowan lithic artifact production: Results and discussion of behavioral lithic classification. PaleoAnthropology 2009: A1-A40.

Rightmire GP (1979) Cranial remains of Homo erectus from Beds II and IV, Olduvai Gorge, Tanzania. American Journal of Physical Anthropology 51(1): 99-115.

Roberts RG, Flannery TF, Ayliffe LK et al. (2001) New ages for the last Australian megafauna: Continent-Wide extinction about 46,000 years ago. Science 292: 1888-1892.

Roebroeks W and Villa P (2011) On the earliest evidence for habitual use of fire in Europe. Proceedings of the National Academy of Sciences 108: 5209-5214.

Rolland N (2004) Was the emergence of home bases and domestic fire a punctuated event? A review of the Middle Pleistocene record in Eurasia. Asian Perspectives 43(2): 248-280.

Rowlett RM (2000) Fire control by Homo erectus in East Africa and Asia. Acta Anthropologica Sinica 19: 198-208.

Ruddiman W (2003) The Anthropocene greenhouse era began thousands of years ago. Climatic Change 61: 261-293.

Schulz E (1993) Human impact and the anthropogenic nature of the west African Sahel. In: Inter-INQUA: Program and Abstracts (Special Publication 73), Canberra, 15-18 April. Canberra: Australian Quaternary Association.

Semaw S, Renne P, Harris JWK et al. (1997) 2.5-million-year-old stone tools from Gona, Ethiopia. Nature 385: 333-336.

Shipman P and Walker A (1989) The costs of becoming a predator. Journal of Human Evolution 18: 373-392.

Sikes NE (1994) Early hominid habitat preferences in East Africa: Palaeosol carbon isotopic evidence. Journal of Human Evolution 27: $25-45$.

Spoor F, Leakey MG, Gathogo PN et al. (2007) Implications of new early Homo fossils from Ileret, east of Lake Turkana, Kenya. Nature 448(9): 688-691.

Stanistreet IG (2012) Fine resolution of early hominin time, Beds I and II, Olduvai Gorge, Tanzania. Journal of Human Evolution 63: 300-308. 
Stollhofen H and Stanistreet IG (2012) Plio-Pleistocene synsedimentary fault compartments, foundation for the eastern Olduvai Basin paleoenvironmental mosaic, Tanzania. Journal of Human Evolution 63: 309-327.

Tamrat E, Thouveny N, Taieb M et al. (1995) Revised magnetostratigraphy of the Plio-Pleistocene sedimentary sequence of the Olduvai Formation (Tanzania). Palaeogeography, Palaeoclimatology, Palaeoecology 114: 273-283.

Ungar PS, Grine FE, Teaford MF et al. (2006) Dental microwear and diets of African early Homo. Journal of Human Evolution 50(1): 78-95.
Wrangham RW (2009) Catching Fire: How Cooking Made Us Human. New York: Basic Books.

Wrangham RW and Carmody R (2010) Human adaptation to the control of fire. Evolutionary Anthropology 19: 187-199.

Wrangham RW, Holland Jones J, Laden G et al. (1999) The raw and the stolen: Cooking and the ecology of human origins. Current Anthropology 40: 567-594.

Zihlman AL and Tanner NM (1978) Gathering and hominid adaptation. In: Tiger L and Fowler HT (eds) Female Hierarchies. Chicago, IL: Beresford Food Services, pp. 163194. 